\begin{tabular}{cc}
\hline International Journal of Aging Research \\
(ISSN:2637-3742)
\end{tabular}

\title{
Mitochondrial Metabolism, Dysfunctions in Senescence Cell and the Possible Interventions through Herbal Medicines
}

\author{
Ferro M., Graubard A., Escalante P., Ledezma R., Channan G., Mia N., Dotres V., Bencomo Y. \\ and Datri $P$.
}

FG Scientifica and Science Department at Nutrition Formulators Inc., Miramar, FI, USA.

\begin{abstract}
The mitochondria are the cell`s powerhouse. They are considered ubiquitous organelles of all eukaryotic cells, being responsible for the cell's life and death cycle. Through stimuli in the environment in which they live, mitochondria can modulate their own biogenesis as well as signal retrograde to the nucleus to modify the structure of their proteins. Since the mitochondrial genome contains only 37 genes, much of the encoding of its proteins depends on the nuclear genome. Thus, the communication between mitochondria and the nucleus seems to be a target of science in understanding the pathologies associated with this organelle. Some medicinal herbs have been shown to influence mitochondrial biogenesis, such as Gynostemma pentaphyllun (GP) and berberine, which increase the phosphorylation of proteins AMPactivated protein kinase (AMPK). Just as GP and berberine phosphorylate AMPK in signaling for mitochondrial biogenesis, the sesquiterpene beta-caryophyllene (BCP) demonstrated positive results in reorganizing mitochondrial transcription factors, being an agonist of the peroxisome proliferatoractivated alpha receptor (PPAR- $\alpha$ ). Another plant derivative, the non-psychoactive cannabinoid known as cannabidiol (CBD), has been showing control in the metabolism of calcium in the mitochondrial matrix. In this review, we seek to get a closer look at the biochemical mechanisms of action of some of these plants, as well as their synergies in the results of different treatments. In the view of oriental medicines, the use of associated medicinal herbs has always been part of their treatment protocols. However, the effectiveness of these treatments in relation to plant synergy can be observed in future clinical trials for better understanding.

Keywords: Mitochondrial Biogenesis; Cell Senescence; Retrograde Signaling; Medicinal Herbs

*Correspondence to Author: Marcelo Ferro

Sciences Department at Nutrition Formulators Inc., 10407 N Commerce Parkway, Miramar, FI 33025 Miramar, FI, USA.

\section{How to cite this article:}

Ferro M., Graubard A., Escalante P., Ledezma R., Channan G., Mia N., Dotres V., Bencomo Y., Datri P.. Mitochondrial Metabolism, Dysfunctions in Senescence Cell and the Possible Interventions through Herbal Medicines. International Journal of Aging Research, 2021; $4: 78$.

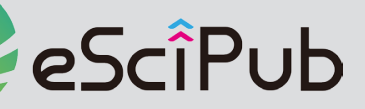

eSciPub LLC, Houston, TX USA. Website: https://escipub.com/
\end{abstract}




\section{Introduction}

Mitochondria are considered ubiquitous organelles in eukaryotic cells, where they are essential for the life cycle and cell death ${ }^{[1]}$. Its structure is formed by two membranes, an internal membrane permeable to ions and an external membrane permeable to factors $<5 \mathrm{kDa}$ [2]. In this structure, mainly in the mitochondrial matrix, adenosine triphosphate (ATP) is generated by oxidative phosphorylation (OXPHOS). An electrochemical gradient across the inner membrane leads to a proton driving force in the intermembrane space that triggers ATP synthesis ${ }^{[3]}$. This process occurs due to electrons donated from reduced forms of nicotinamide adenine dinucleotide (NADH) and flavin adenine dinucleotide (FADH2) generated by the oxidation of acetyl-CoA in the tricarboxylic acid (TCA) cycle ${ }^{[4]}$. Under normal conditions, the oxidation of certain energy substrates, especially fatty acid and glucose-pyruvate, generates acetyl CoA in the mitochondrial matrix ${ }^{[4]}$. Electrons from NADH and FADH are transferred through the electron transport chain (ETC) components in the inner mitochondrial membrane. The transfer of electrons along the ETC induces the flow of protons through the inner membrane reaching the intermembrane space. Upon returning to the mitochondrial matrix, the protons trigger an enzyme also known as ATP synthase, which makes it possible to synthesize ATP (Fig 1) ${ }^{[5]}$.

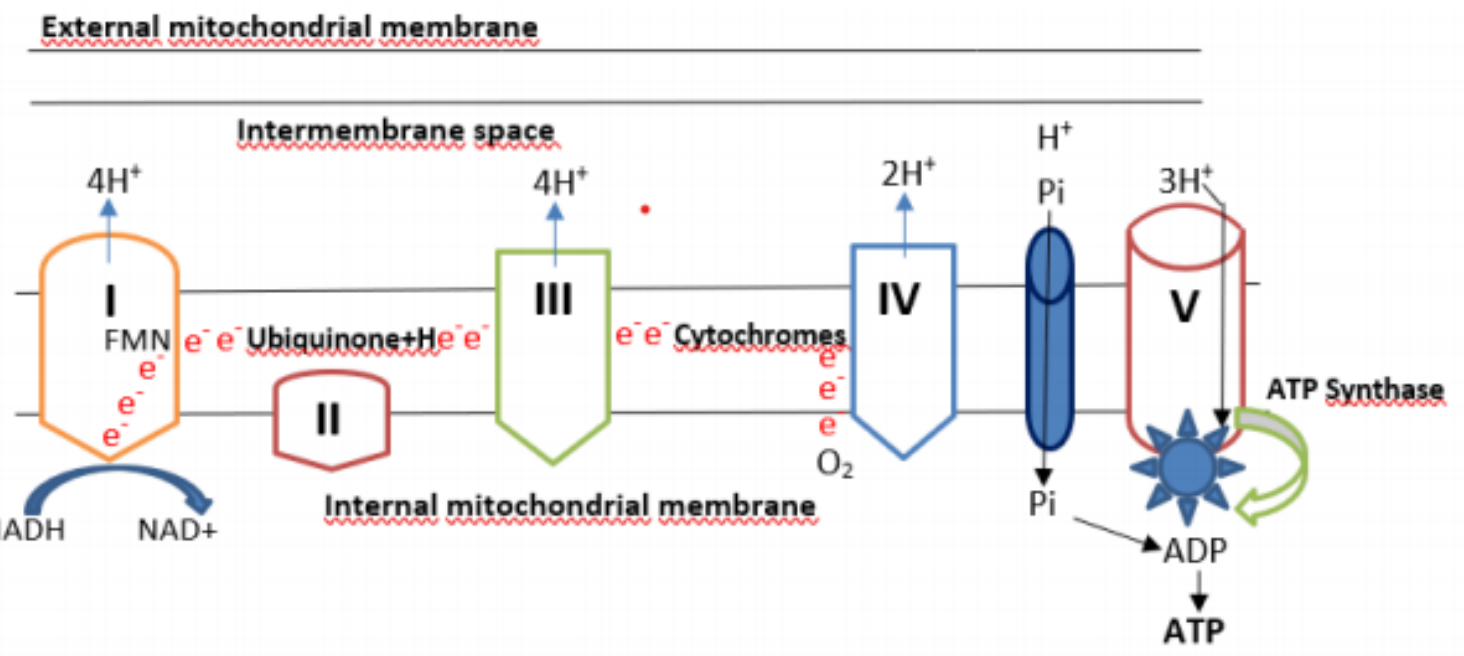

Figure 1

\section{Mitochondrial biogenesis}

Mitochondrial biogenesis is a highly complex process ${ }^{[6]}$. For a better understanding of how this whole process works, it is necessary to first examine the gene transcription factors involved in this mechanism ${ }^{[7]}$.

Bearing in mind that the control of activation or deactivation of genes comes from signals originating from the environment in which cells live, such as food intake, thought processing, sensitivity to temperature and light intensity, the process of signaling mitochondrial biogenesis is no different ${ }^{[8]}$. Upon receiving stimuli such as cold and fasting, a protein CAMP response element-binding protein (CREB) is phosphorylated through another signaling protein, protein kinase A (PKA) ${ }^{[9,10]}$. Once phosphorylated, the CREB protein will continue the transcription process by phosphorylating the 
peroxisome proliferator-activated receptorgamma coactivator-1alpha (PGC-1 $\alpha$ ) (Fig. 2) ${ }^{[11]}$. Likewise, there is another metabolic route that occurs through physical exercise, where calcium binds to two proteins, calmodulin-dependent protein kinase IV (CaMKIV) and calcineurin A $(\mathrm{CnA})$, which can activate phosphorylation of CREB protein, and, consequently, promote signaling for peroxisome proliferator-activated receptor-gamma coactivator-1alpha (PGC-1a) transcription ${ }^{[12]}$. Once the expression of PGC$1 \alpha$ is increased, there is a sequence for the transcription of specific proteins that interact in the process, not only of protein synthesis of the respiratory chain, but also of the replication of this organelle, among them myocyte enhancement factor 2 (MEF-2) [13], nuclear respiratory factor 1 and 2 (NRF-1 and NRF-2) ${ }^{[14]}$, the estrogen-related alpha receptor (EER- $\alpha)^{[15]}$, and also the receptors activated by the peroxisome proliferator-activated receptor alpha $(\text { PPAR- } \alpha)^{[16]}$, the latter being responsible for the formation of proteins that carry out beta oxidation in mitochondria. A curious fact that deserves attention is that MEF-2, like CREB, interacts in the PGC-1 $\alpha$ transcription process ${ }^{[11]}$. Subsequently, MEF-2 is activated by PGC-1a itself, where it will be transferred into the mitochondria, triggering the transcription of cytochrome c oxidase (Fig. 2) ${ }^{[17]}$. This path is not yet well known to its full extent, but it seems that there is a loop between the process in activating the transcription of both.

Another no less important factor about PGC-1a signaling is the activation of the AMP-activated protein kinase (AMPK) (Fig. 2) ${ }^{[18]}$. This protein is highly expressed in catabolic processes, such as physical activity [19]. As a result of a power outage, AMPK is strongly phosphorylated, increasing it signaling to PGC-1 ${ }^{[20]}$. Thus, the other signaling proteins of the mitochondrial biogenesis mentioned above initiate a biochemical cascade not only for protein synthesis but also for the replication of the mitochondrial genome itself, mainly related to the respiratory chain [7]. There is also a transcription protein synthesized in the cytoplasm of cells, called mitochondrial transcription factor (TFAM), which plays a fundamental role in the maintenance of mitochondrial proteins, both in transcription and in the replication of this organelle ${ }^{[21]}$. However, not only do these factors interact in maintaining the health of mitochondria, but their own genome also has a strong interaction for the preservation of their structures ${ }^{[22]}$.

\section{Mitochondrial genome}

The mitochondrial genome, unlike the nuclear genome, is circular and has 16,569 DNA base pairs, whereas the nuclear genome contains 3.3 billion DNA base pairs ${ }^{[22,23]}$. The mitochondrial genome is made up of only 37 genes [23]. However, in each protein in the respiratory chain, there is bilateral participation between the nuclear genome together with the mitochondrial genome (Fig. 3) ${ }^{[24]}$. For example, in complex I of the respiratory chain, where the entire electron flow process begins, 39 genes come from the nucleus with only seven coming from mitochondria ${ }^{[25]}$. In complex II, the four genes come exclusively from the nucleus, with no involvement of the mitochondrial genome in this protein ${ }^{[26]}$. In complex III, ten are nuclear and only one mitochondrial ${ }^{[27]}$. In complex IV, we have ten nuclear and three mitochondrial cells [28]. In complex $\mathrm{V}$, we have 14 nuclear and two mitochondrial ${ }^{[28]}$. Researchers also claim that mitochondrial DNA (mtDNA) is inherited exclusively from the female ${ }^{[29]}$. This is due to the presence of mitochondria in the cytoplasm of the egg when they are assigned to the zygote, or unicellular embryo ${ }^{[30]}$. In the case of sperm, 
mitochondria end up being eliminated by scientific reports of paternal mitochondrial process of ubiquitination as soon as it enters the inheritance in humans ${ }^{\left[{ }^{32}\right]}$. This fact is due to a egg ${ }^{[31]}$. Once fertilized, this cell will replicate genetic mutation in the maternal mitochondrial mitochondrial DNA only from the mother [29]. DNA itself, which makes it possible to inherit the However, despite the rarity, there have been paternal mitochondrial genome ${ }^{[33]}$.

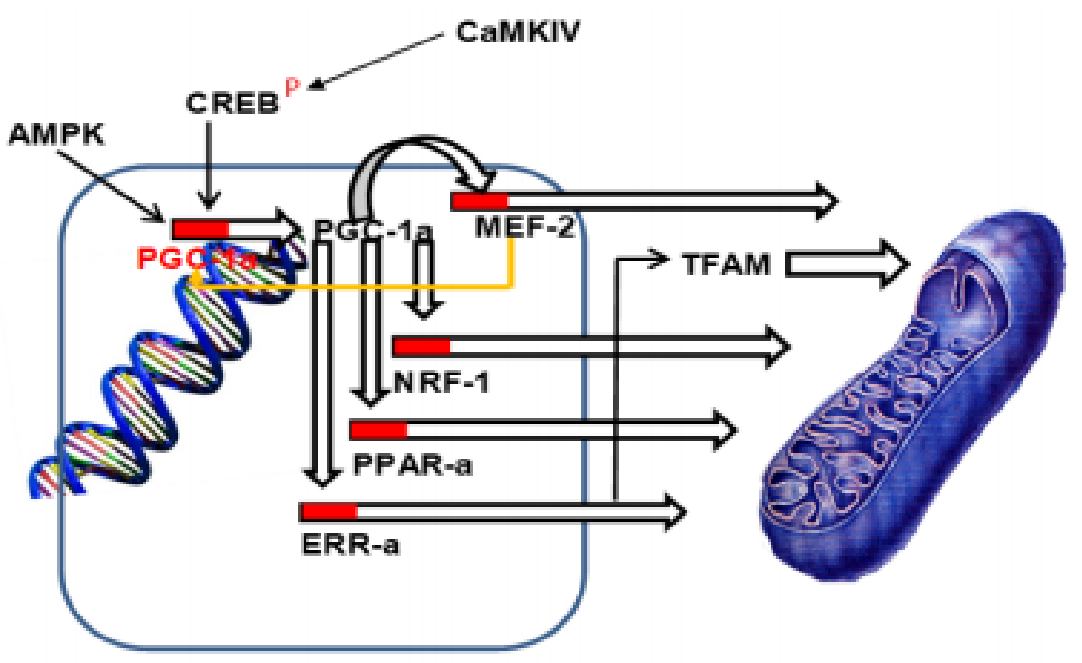

Figure 2

CaMKIV, Calcium/calmodulin-dependent protein kinase IV; CREB, cAMP response element-binding protein; AMPK, Adenosine monophosphate kinase; PGC-1 $\alpha$, Peroxisome proliferator-activated receptor-gamma coactivator-1alpha; MEF-2, myocyte enhancer factor-2; NRF-1, Nuclear respiratory factor 1; PPAR- $\boldsymbol{\alpha}$, Peroxisome proliferator-activated receptor alpha; ERR-a, Estrogen-related receptor alpha; TFAM, Transcription Factor A, Mitochondrial.

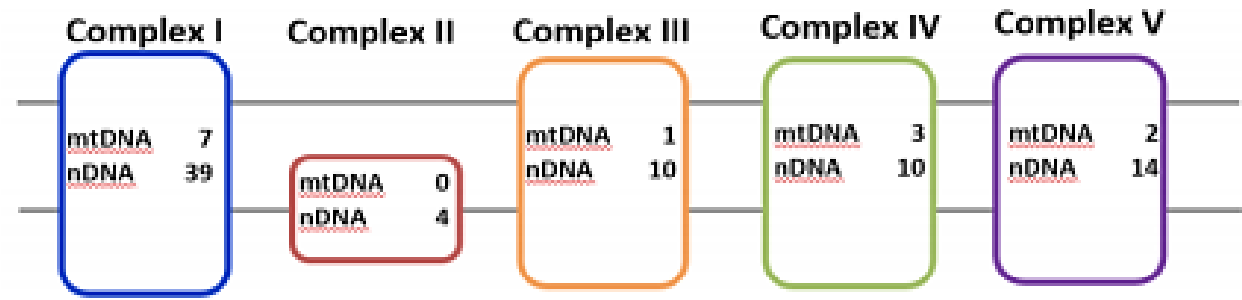

Figure 3

\section{Mitochondria and Senescent Cells}

Cellular senescence is increasingly recognized as the main cause of health loss and physical conditioning associated with aging [34]. The amount of dysfunctional mitochondria in senescent cells is a reality that has been reported in several scientific studies, and its inefficiency of OXPHO and the increase in reactive oxygen species (ROS) trigger serious damage to cells ${ }^{[35]}$. Mitochondrial enzymes need to be in perfect working order to synthesize ATP in the ideal amounts for cell functioning ${ }^{[36]}$. Any enzymatic change linked to the production of energy in these organelles can seriously compromise the functioning of tissues ${ }^{[37]}$. When mitochondria are not working well, a wide variety of symptoms can arise, including delay or regression in physical and mental development 
[38], impaired language [39], impaired social have a major and important influence on several interaction [40], intellectual disability [38,40], health conditions, such as autism [47, 48], bipolar neuropsychiatric symptoms (ADHD, anxiety, disorder [49], schizophrenia [49], depression [50], OCD, depression) ${ }^{[41]}$, seizures ${ }^{[40]}$, headaches cancer ${ }^{[51,52]}$, diabetes ${ }^{[53]}$, Parkinson's disease ${ }^{[42]}$, hearing problems ${ }^{[40,43]}$, weakness ${ }^{[42]}$, short ${ }^{[54]}$, asthma ${ }^{[55]}$, chronic fatigue syndrome ${ }^{[44,45]}$, stature ${ }^{[38,42]}$, fatigue ${ }^{[44,45]}$, gastrointestinal Alzheimer's disease [56], gastrointestinal symptoms [40], endocrine disorders [46], and disorders ${ }^{[40]}$, nonalcoholic fat liver disease [57] many others. More and more research now and several others. suggest that mitochondrial dys- function can

Table 1

\begin{tabular}{lccc}
\hline S. no. & Disease & Mitochondrial changes & Reference \\
\hline 1 & Autism & †ROS $\downarrow$ NADH oxidase activity & Giulivi et al. (2010) \\
2 & Bipolar disorder and schizophrenia & $\downarrow$ mt Respiration $\uparrow$ mtDNA mutation & Clay et al. (2011) \\
3 & Depression & Alteration of OXPHOS $\uparrow$ ROS & Allen et al. (2018) \\
4 & Cancer & mtDNA mutations & Wallace (2012) \\
5 & Diabetes & $\downarrow$ ATP Production $\uparrow$ ROS & Sivitz \& Yorek (2009) \\
6 & Parkinoson's disease & Complex I deficiency & Chen et al. (2019) \\
7 & Asthma & mtDNA alteration $\uparrow$ ROS & Reddy (2012) \\
8 & Chronic Fatigue Syndrome & $\downarrow$ ATP Production & Myhill et al. (2009) \\
9 & Alzheimer's disease & mtDNA oxidation/mutations $\uparrow R O S$ & Cenini \& Voos (2019) \\
10 & Fat Liver & Depletion of mtDNA $\downarrow$ OOXPHOS $\uparrow \beta$-oxidation & Wey et al. (2008) \\
\hline
\end{tabular}

In a study on mitochondria in senescent cells, the authors Korolchuk et al (2017) demonstrated that cell senescence is increasingly recognized as the main contributor to health loss and especially in decreasing physical conditioning associated with aging [58]. Furthermore, it has been shown that senescent cells accumulate dysfunctional mitochondria, mainly in the metabolism of oxidative phosphorylation, leading to high production of reactive oxygen species ${ }^{[58]}$. Because cell senescence is part of a range of cellular responses to extrinsic and / or intrinsic harmful processes that affect homeostasis, especially the integrity of both the genome and the proteome ${ }^{[59]}$, studies have suggested that unregulated mitochondrial fusion, fission and mitophagies have been observed in cell senescence. These studies have shown that,in senescent cells, mitochondrial dynamics are strongly reduced [60]. Stress-induced premature senescence showed elongated mitochondria, with increased crest structure, as well as increased mitochondrial content [61]. Although studies are already well documented about mutations in mtDNA as a cause of different types of mitochondrial diseases ${ }^{[62]}$, the impact of this mutation as a senescence factor has not been well investigated ${ }^{[63]}$. In the past, the first studies excluded the presence of deletions or single base changes in mtDNA ${ }^{[64]}$. However, more recently it was demonstrated in cell cultures that mtDNA depletion exhibited senescent phenotypes, characterizing the potential involvement of mtDNA damage in cell 
senescence ${ }^{[65] . ~ I n ~ f a c t, ~ r e c e n t ~ s t u d i e s ~ s u p p o r t ~}$ the idea that all the nucleus-derived transcription factors mentioned above that govern mitochondrial biogenesis, PGC-1 $\alpha$, NRF-1/2, sirtuins and TFAM are somehow involved in cell senescence ${ }^{[63]}$ (Fig 2).

\section{Retrograde Signaling in Mitochondrial Dysfunction}

In mammalian cells, retrograde mitochondrial signaling is well understood by the scientific community. This process occurs due to an altered nuclear expression in response to mitochondrial dysfunction with a series of signaling pathways involved in this communication [66]. From studies on metabolic diseases, inflammation and cancer, we have an extensive list of important small molecules participating in retrograde mitochondrial signaling, including ROS, NAD+ / NADH ratio, Acetyl-CoA, ATP, Ca2+, and oncometabolite [67]. Enzymes such as calcineurin, protein kinase- $C$ (PKC), CaMKIV, c-Jun N-terminal kinases (JNK) and mitogen activated protein kinase (MAPK), as well as the transcription factors activating transcription factor 2 (ATF2), CCAAT/enhancerbinding protein- $\delta$ (C/EBP- $\delta$ ), nuclear factor of activated T cells (NFAT), CREB, early growth response protein 1 (Egr-1), C/EBP homologous protein (CHOP) and nuclear factor kappa-beta (NF-KB) participate in the retrograde mitochondrial signaling of mammals ${ }^{[68]}$ (Fig. 4). Research has reported that, depending on cell type and cell conditions, there are essentially two branches in the $\mathrm{Ca} 2+$ mediated retrograde signaling pathway: 1 . Ca2+ mediated retrograde signaling / calcineurin for nuclear translocation of transcription factors, NF- $\mathrm{kB}$, NFAT, CREB and heterogeneous nuclear ribonucleoprotein A2 (HnRNPA2); and, 2. Direct activation of Ca2+ dependent protein kinases, such as those previously mentioned, PKC, JNK, MAPK and
CaMKIV [67]. The activation of these signaling pathways in epithelial cells converges in the positive regulation of genes that affect several cellular functions, including resistance to apoptosis and resistance to multiple drugs ${ }^{[69]}$. On the other hand, retrograde signaling is triggered by a mitochondrial signal, which, in turn, is relayed to one or more protein molecules that reach the nucleus. Oncometabolites, for example, are metabolites whose abundance is significantly increased in cancer cells compared to normal cells ${ }^{[70]}$. Increasing evidence shows that oncometabolite and retrograde signaling contributes to cancer progression [67,70]. Research has already shown the retrograde signaling involved in epigenetic changes and post-translational protein modifications, including proto oncogene c-Src, MAPK, AMPK, poly (ADP ribose) polymerase (PARP) and sirtuin 1 (SIRT1) in various pathological

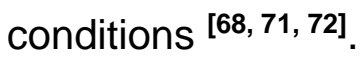

\section{Medicinal Herbs}

The plant kingdom has adapted to all habitable environments on planet Earth. Because they are inanimate beings, the challenges related to environmental stress caused several species of plants to develop many molecules to avoid animal attacks and other environmental aggressions ${ }^{[73]}$. These molecules synthesized by plants give the ability to exhale fragrances, colors and even toxicity as a protective

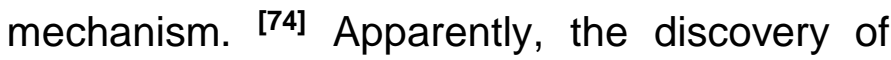
medicinal plants by the first humans may have been an exercise in trial and error due to the need to relieve the manifestations of symptoms, such as pain, inflammation and allergic reactions to insect bites ${ }^{[75]}$. In the beginning, before the advent of writing, this knowledge was transmitted from generation to generation through word of mouth. Later, many plants were registered as having medicinal properties and 
were used to treat many diseases ${ }^{[76]}$. Several in recent decades, the increase in the use of natural products from plants and animals have medicinal plants in the treatment of diseases has been the source of medicines, especially for shown remarkable results in many countries, anticancer and antimicrobial agents [77, 78]. including developed countries such as the Throughout history, especially in the 20th United Kingdom, Germany, France and others century, traditional medicine has been [80, 81, 82]. In fact, many extracts of medicinal overshadowed by modern medicine as a means plants are being used as prescription drugs with of treatment for human diseases ${ }^{[79]}$. However, promising results in several pathologies ${ }^{[83]}$.

\section{Mammal}
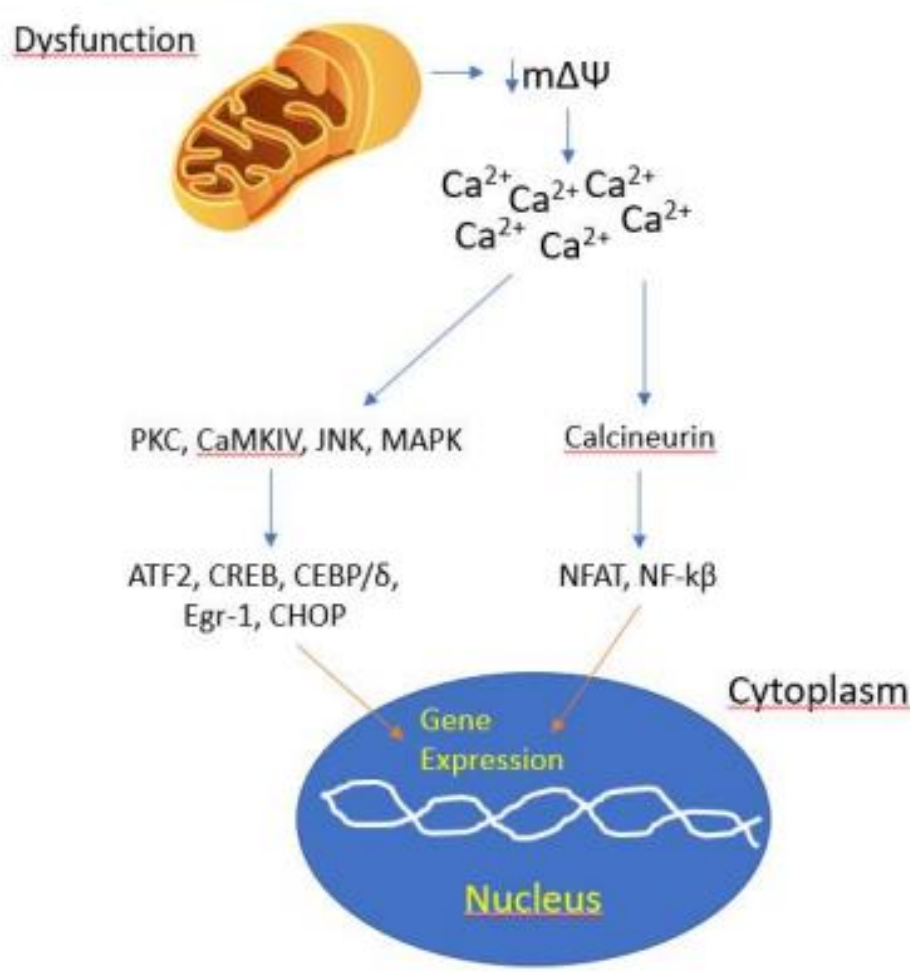

Figure 4

$\mathbf{m} \boldsymbol{\Delta} \boldsymbol{\Psi}$, Mitochondrial membrane potential; PKC, Protein Kinase C; CaMKIV, Calcium/calmodulin-dependent protein kinase IV; JNK, C-Jun N-terminal kinases; MAPK, mitogen-activated protein kinase; ATF2, Activating Transcription Factor 2; CREB, CAMP response element-binding protein; Erg-1, Early growth response protein 1; CEBP-ठ, CCAAT/enhancer-binding protein delta; CHOP, C/EBP homologous; NFAT, Nuclear factor of activated T-cells protein;

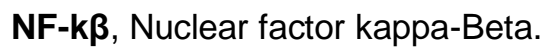

Beta-caryophyllene (BCP), for example, is a sesquiterpene found in several types of plants, mainly in Cannabis Sativa ${ }^{[84]}$. This resin has remarkable anti-inflammatory properties, as well as antitumor activity, including the induction of apoptosis by inhibiting B-cell lymphoma 2 (Bcl-2) activity ${ }^{[85]}$. BCP also features the ability to rearrange the mitochondrial transcription factors, suffering retrograde signaling in this type of pathology [86]. Thus, the BCP works as a peroxisome proliferator-activated receptor alpha (PPAR- $\alpha$ ) agonist, one of the most important transcription factors in mitochondrial biogenesis [87]. Intriguingly, PPAR- $\alpha$ is predominantly 
present in many cells, including in the liver. Previous studies have demonstrated that PPARa plays a critical role in the modulation of energy balance and regulation of hepatic lipid through mitochondrial metabolism [88]. Another mechanism of inflammatory protection exerted by $\mathrm{BCP}$ is to restore antioxidant enzymes in mitochondria, mainly superoxide dismutase (SOD), and inhibited lipid peroxidation as well as glutathione (GSH) depletion in neurons ${ }^{[89]}$.

Similar to the mechanisms of action of BCP, beta-caryophyllene oxide (BCPO), due to its high biological activity, was extensively studied in recent years ${ }^{\left[{ }^{[9]}\right.}$. Either as a pure substance or a component of plant essential oils, BCPO was found to exhibit anti-inflammatory, antioxidant, antiviral, anticarcinogenic, and analgesic properties even better than BCP, mainly in anticarcinogenic activity [90, 91]. BCPO induced increased ROS generation from mitochondria, which is associated with the induction of apoptosis as characterized by positive Annexin $\mathrm{V}$ binding and TUNEL staining, loss of mitochondrial membrane potential, the release of cytochrome c, activation of caspase-3, and cleavage of PARP (Poly (ADP-ribose) polymerase) ${ }^{\text {[92] }}$. Proapoptotic activity of BCPO in cancer cells can be associated with reduced activation of NF - $\mathrm{k} \beta{ }^{[90]}$. NF - $\mathrm{k} \beta$ regulates the expression of many genes involved in cellular proliferation, apoptosis, and inflammation (e.g., TRAF-TNF receptor - associated factor, c FLIP_cellular FLICE - like inhibitory protein, surviving, various chemokines, and cytokines) [93]. Studies reported BCPO - induced inhibition of the constitutive and inducible NF - $\mathrm{k} \beta$ activities in cancer cells. Moreover, they found that BCPO increased the tumor necrosis factor $\alpha$ (TNF- $\alpha$ ) and caused apoptosis by inhibiting the $N F-k \beta$ activation ${ }^{[94]}$.
Another plant that exerts antitumor activity associated with mitochondrial metabolism is Artemisia annua ${ }^{[95]}$. Artemisia annua has been described for over two thousand years in Traditional Chinese Medicine due to its feverreducing capability ${ }^{[96]}$. In tumor cell artemisinin induce apoptosis by increasing metabolism, elevated concentration of iron and transferrin, and consequently increasing ROS [97]. Studies suggested that low doses of artesunate, a derivate of Artemisia annua, induced oncosislike cell death, characterized by cytoplasmic swelling and vacuolization, disorganized mitochondria, dilation of the nuclei, and cell lysis

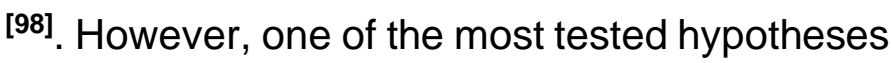
about artemisinin, another derivate of Artemisia annua, is that the endoperoxide bridge of the artemisinin structure reacts with either heme groups or intracellular iron, hence producing cytotoxic radicals with an alkylating capacity ${ }^{[99}$, 100, 101]. The importance of iron in mitochondrial function is well known. However, the role of mitochondrial iron trafficking in the regulation of cellular iron homeostasis is not well understood [102]. In mitochondria, iron is used for the synthesis of heme and the generation of ironsulfur ${ }^{[99]}$. Thus, linking artemisinin to transport into the mitochondria matrix is an interesting path [103]. Once inside the mitochondria, artemisinin has greater contact with iron, pulling an electron from that metal in its endoperoxide portion, causing the formation of ROS and consequently ferroptosis ${ }^{[104]}$. Still in relation to mitochondrial metabolism, studies related

that apoptosis of human umbilical vein endothelial cells (HUVEC) by artesunate and artemisinin is associated with negative regulation of $\mathrm{Bcl}-2$ and positive regulation of BAX (protein $X$ associated with $\mathrm{Bcl}-2$ ), the genes associated with the control of apoptosis in the external mitochondrial membrane ${ }^{[105,106]}$. 
As apoptosis depends on the metabolism of calcium, cannabidiol (CBD), present in Cannabis sativa, exerts an important mechanism on the balance of mitochondrial calcium in the mechanism of control of apoptosis ${ }^{[107,108]}$. CBD is a non-psychoactive plant cannabinoid that inhibits cell proliferation and induces cell death of breast cancer cells ${ }^{[109]}$. Studies have shown that CBD-mediated cytosolic elevation of free $\mathrm{Ca} 2+$ has been observed in several cells, cancerous and non-cancerous [110], and its presence defines the scenarios of cell destiny, survival or death [111]. Elevated intramitochondrial $\mathrm{Ca} 2+$ is a prerequisite for the formation of mitochondrial permeability transition pore (PTP20), and consequently, apoptosis ${ }^{[112]}$. Usually, the increase in intramitochondrial $\mathrm{Ca} 2+$ is triggered by an increase in cytosolic $\mathrm{Ca} 2+$. In most cases, the source of $\mathrm{Ca} 2+$ can be via the endoplasmic reticulum (ER), whose membrane is very close to the external mitochondrial membrane (OMM), facilitating the transposition of $\mathrm{Ca} 2+{ }^{[113]}$. Thus, CBD interacts directly with mitochondrial calcium. Its effect does not depend on cannabinoid receptors or $\mathrm{Ca} 2+$ permeable channels in the plasma membrane. Instead, CBD targets the mitochondria directly by altering $\mathrm{Ca} 2+$ metabolism [109]. In lethal concentrations, CBD causes $\mathrm{Ca} 2+$ mitochondrial overload, the formation of stable mitochondrial transition pores and cell death [114]. Studies have suggested that CBD is an attractive candidate to be included in chemotherapy protocols for the treatment of acute lymphoblastic leukemia of $T$ lineage ( $T$ ALL) for its proapoptotic activity in these cell types ${ }^{[109] .}$

As we can see, mitochondrial metabolism is associated with numerous pathologies. Thus, controlling mitochondrial biogenesis seems to be a promising path for the treatment of several diseases [115], mainly when medicinal herbs manage to activate the signals of the transcription factors involved in mitochondrial biogenesis, as in the case of berberine and jyagulan (Gynostemma Pentaphyllun) ${ }^{[116,117] .}$

Berberine is a natural isoquinoline alkaloid derived from the traditional medicinal plant Coptis chinensis that has numerous pharmacological properties, including antimicrobial, antioxidant, anti-inflammatory, antidiarrheal, antidiabetic, antilipidemic and antitumor activities ${ }^{[116]}$. Studies have shown beneficial effects of berberine in the treatment of insulin sensitivity and glucose tolerance due to berberine's ability to activate AMPK and suppress gluconeogenesis [118, 119]. Berberine can also activate SIRT1, a protein that has a twoway pathway in regulating AMPK ${ }^{[120,121,122]}$. In other words, SIRT1 can be regulated by AMPK as well as regulating AMPK activity. Thus, berberine has been shown to be effective both in increasing mitochondrial biogenesis and in mitochondrial function in muscle tissue of obese rats ${ }^{[120]}$.

Following a metabolic pathway like berberine, studies have reported that Gynostemma pentaphyllun (GP) has also shown remarkable properties in AMPK phosphorylation [117]. Since AMPK is a key sensor and regulator of glucose, lipid and energy metabolism ${ }^{[121]}$, its activation by GP improves metabolic abnormalities associated with metabolic diseases, including obesity and type 2 diabetes ${ }^{[123]}$. Studies have found that GP contains two saponins, also know as damulins, which activate AMPK strongly [117]. These damulins also act positively in the metabolism of $\beta$-oxidation and in the uptake of glucose by increasing the translocation of GluT4 to the plasma membrane in L6 myotubular cells [117]. A study comparing the effect of GP with a control diet and a high-fat diet showed that GP 
significantly increased SIRT1 mRNA expression, as well as AMPK phosphorylation when compared to both control groups, and especially to the high fat intake group ${ }^{[23]}$. Several other studies have reported that GP can bring promising results in the control of metabolic syndrome by improving the function of mitochondrial metabolism and SIRT1 expression [124, 125, 126].

Interestingly, SIRT1 is an epigenetic enzyme involved in protein deacetylation that acts mainly as a metabolic sensor responding to changes in the energy state, deacetylation of transcription factors and crucial cofactors in cellular metabolism [127]. This enzyme also regulates several biological functions, including biogenesis, inflammation, apoptosis, oxidative stress, mitochondrial function and cellular senescence [128]. Several studies have shown that resveratrol has a good impact on SIRT1 ${ }^{[129,130]}$. Resveratrol is a naturally occurring polyphenolic component that belongs to the class of stilbenes present in more than 70 species of plants, mainly in the skin of red grapes [131]. Studies have shown that resveratrol has inhibitory effects on various types of cancer cell lines and preclinical animal models in many types of cancer, such as colon, breast and lymphoma, due to its activity on several subcellular targets, including SIRT1 ${ }^{[132]}$. In fact, resveratrol uses several strategies to stimulate apoptosis in cancer therapy. One of them is to increase the level of mitochondrial oxidative stress, which, in turn, releases cytochrome $\mathrm{C}$ in the cytosol, activating the caspases and triggering apoptosis ${ }^{[133]}$. It was observed that the administration of resveratrol triggered a mitochondrial dysfunction due to the loss of the mitochondrial membrane potential, resulting in the induction of apoptosis in tumor

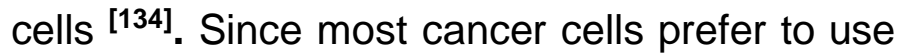
glycolysis to generate ATP and simultaneously increase their glucose uptake (Warburg effect), the antitumor activity shown by resveratrol caused, at the same time, a reduction in glucose metabolism in cancer cells, as well as the induction of mitochondrial breathing in cancer

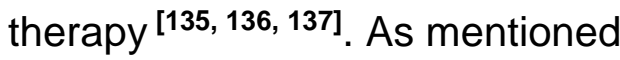

above, there is a bidirectional interaction between the SIRT1 pathway and the AMPK. Therefore, it has been reported that the SIRT1 / AMPK axis is important in the mitochondrial biogenesis, fission, fusion and mitophagy of this organelle [138], and resveratrol administration had antitumor impacts by affecting mitochondrial breathing through positive regulation of SIRT1 [139].

\section{Discussion}

Mitochondria are increasingly in evidence in the focus of treatment of various diseases. It is so important for cells that recently studies have tried to understand the transit of this organelle in extracellular spaces. In March 2020, Dache et al. published an article with surprised researchers since intact mitochondria was found in the extracellular space ${ }^{[140]}$. While several other studies have reported the existence of extracellular mitochondria under specific conditions resulting in platelet activation or encapsulated in microvesicles, the authors Dache et al. (2020) stated that it is remarkable how the presence of mitochondria free of intact cells went unnoticed in the normal physiological state. Studies have pointed out that intact mitochondria free of circulating cells have crucial biological and physiological roles, as it was scientific knowledge that mitochondria function as systemic messengers in cell-cell communication through the transfer of hereditary and non-hereditary constituents [140, 141]. Previous studies also have already reported that mitochondria translocate from one cell to another. These studies demonstrated that the 
intercellular mitochondria traffic occurred both in vitro and in vivo, and in both physiological and pathophysiological conditions, including tissue damage and cancer ${ }^{[142,143]}$.

In either of these processes, a transit of mitochondria between cells was observed. Patel et al. (2017) also demonstrated that mitochondria could be internalized by different types of cells, such as, for example, macropinocytosis, which is a specific endocytic pathway for large vesicles [144]. However, although clinical mitochondrial transplants between cells are an active area of research, the specific mechanisms and critical factors involved in the natural transfer of mitochondria between donor cells and recipient cells have yet to be fully characterized ${ }^{[145]}$.

Table 2

\begin{tabular}{|c|c|c|c|}
\hline S. no. & Herbs & Mitochondrial Interaction & Reference \\
\hline 1 & Beta-caryophyllene & $\begin{array}{l}\text { 'Bcl-2 } \uparrow \text { ↔BAX (pro apoptosis cancer cell) } \\
\text { PPAR- } \alpha \text { (mitochondrial biogenesis) }\end{array}$ & $\begin{array}{l}\text { Legaut \& Pichet (2007) } \\
\text { Yussef et al. (2019) }\end{array}$ \\
\hline 2 & Beta-caryophyllene oxide & $\uparrow$ TNF- $\alpha \downarrow N F-k \beta$ (pro apoptosis cancer cell) & Kim et al. (2014) \\
\hline 3 & Artemisia annua & $\downarrow \mathrm{Bcl}-2 \uparrow \mathrm{BAX}$ (ferroptose cancer cell) & Li et al. (2013) \\
\hline 4 & Cannabidiol & Ca+2 PTP20 (apoptosis) & Giorgio et al. (2018) \\
\hline 5 & Berberine & AMPK (mitochondrial biogenesis) & Teodoro et al. (2013) \\
\hline 6 & Gynostemma pentaphyllun & AMPK (mitochondrial biogenesis) & Gauhar et al. (2012) \\
\hline 7 & Resveratrol & SIRT1 (mitochondrial biogenesis) & Buhrmann et al. (2019) \\
\hline
\end{tabular}

Numerous studies have been looking for therapies on how to preserve mitochondrial structures, especially in mtDNA, with the administration of drugs, herbal medicines and nutraceutical products ${ }^{[125,139]}$. In both cases, such as importing healthy mitochondria into dysfunctional tissues, as well as administering phytochemicals to rescue the integrity of the mitochondria in dysfunctional tissue, research has shown to be increasingly favorable to the treatment of mitochondria in relation to associated diseases. The many herbs reported in this present study had medicinal properties aimed directly and/or indirectly at mitochondria in various diseases. This makes us reflect on how influential mitochondria are in diseases as well as in aging. Another hypothesis that could be answered in future clinical trials would be how much the retrograde mitochondrial signaling would be related to the cause of diseases such as cancer, for example. What science has known until now is that the membrane morphology of these organelles undergoes radical changes in diseases such as Alzheimer's disease, Parkinson's, non-alcoholic liver cirrhosis and cancer itself [146]. Rescuing the IJOAR: https://escipub.com/international-journal-of-aging-research/ 
anterograde signals, that is, from the nucleus to the mitochondria under normal conditions, could be a hypothesis to help reverse diseases associated with mitochondria. Once retrograde signaling is activated because of chronic stress, altering the expressions of certain genes that would modify mitochondrial structures is a fact. Administering herbal medicines and specific coenzymes that act in the respiratory chain seems to be an interesting way of controlling oxidative stress and reversing retrograde signaling processes ${ }^{[86,110,115,116,117,134]}$.

Another factor to be observed would be a possible administration of plants synergistically in the control of mitochondrial apoptosis. For example, piperlungumine, the biologically active compound from the Piper longum plant, when it is administered, a reduction in reduced glutathione levels is observed in cancer cells by inhibiting the enzyme glutathione reductase (GR) [147]. This would be fantastic if this type of cell did not defend itself by increasing the expression of nuclear factor erythroid 2-related factor 2 (Nfr-2). With the increase in Nfr-2, cancer cells can produce more antioxidants counterbalancing the reduction of glutathione by piperlungumin protect itself ${ }^{[148,149]}$. However, the use of luteolin, a flavonoid found in several plants, can inhibit of Nfr-2 activity in cancer cells ${ }^{[150]}$. Therefore, the effects of piperlungumine in controlling mitochondrial glutathione levels are likely to be a promising path in herbal therapies when used in synergy with another herb such as luteolin. In the same way that drugs must be administered together to treat certain diseases, medicinal plants also follow the same reasoning.

\section{Conclusion}

Pathologies directly or indirectly related to mitochondria have been the target of studies in several types of diseases. Since enzymatic changes in mitochondrial metabolism, as well as changes in the genome of this organelle are decisive factors in disease control, the scientific community is increasingly committed to understanding not only the functioning of mitochondria but mainly why this imbalance in its metabolism occurs in diseases. A classic example of this is the retrograde signaling between the mitochondria and the cell nucleus, as related above. Likewise, changes both environmental and emotional, as well as inadequate food intake, can cause a series of changes in the structures of mitochondria, especially in the transcription factors that modulate mitochondrial genome. Therefore, understanding how to control mitochondrial imbalance in the fight against pathologies is a necessary tool to be applied, especially when we talk about medicinal herbs which have the capacity to control the proteins involved in mitochondrial biogenesis (AMPK, PPARs e etc.). However, future studies will be needed to evaluate the results of medicinal herbs, especially when they are administered concomitantly, as well as in Traditional Chinese Medicine and Ayurvedic Medicine, and not just alone. Some studies have already shown that the synergy between medicinal herbs can really bring benefits in different treatments, but no clinical study has yet been proposed to treat mitochondrial diseases to date. As mitochondrial changes are extensive in several diseases, the proposal to administer different medicinal herbs that act in different areas of mitochondrial metabolism seems to be an interesting path from the biochemical point of view to be investigated.

\section{Reference}

[1] FERNANDEZ-MORENO MA, BORNSTEIN B, PETIT N, GARESSE R. The pathophysiology of Mitochondrial Biogenesis: Towards Four Decades of Mitochondrial DNA Research. 
Molecular Genetics and Metabolism. 71, 481495 (2000).

[2] BALABAN RS. 1990. Regulation of oxidative phosphorylation in the mammalian cell. Am J Physiol 258: C377-C389.

[3] DORN GW, VEGA RB, KELLY DP. Mitochondrial biogenesis and dynamics in the developing and diseased heart. Genes Dev. 2015 Oct 1; 29(19): 1981-1991.

[4] Stanley WC, Recchia FA, Lopaschuk GD. Myocardial substrate metabolism in the normal and failing heart. Physiol Rev. 2005 Jul; 85(3):1093-129.

[5] BHARGAVA P, SCHNELLMANN RG. Mitochondrial energetics in the kidney. Nat Rev Nephrol. 2017 Oct; 13(10): 629-646.

[6] POPOV L. Mitochondrial biogenesis: An update. J Cell Mol Med. 2020 May; 24(9): 4892-4899.

[7] JORNAYVAZ FR, SHULMAN GI. Regulation of mitochondrial biogenesis. Essays Biochem. 2010; 47: 10.1042/bse0470069.

[8] SIGISMUND S, CONFALONIERI S, CILIBERTO A, POLO S, SCITA G, DI FIORE PP. Endocytosis and Signaling: Cell Logistics Shape the Eukaryotic Cell Plan. Physiol Rev. 2012 Jan; 92(1): 273-366.

[9] WANG H, XU J, LAZAROVICI P, QUIRION R, ZHENG W. cAMP Response Element-Binding Protein (CREB): A Possible Signaling Molecule Link in the Pathophysiology of Schizophrenia. Front. Mol. Neurosci., 30 August 2018

[10] ALTAREJOS JY AND MONTMINY M. CREB and the CRTC co-activators: sensors for hormonal and metabolic signals. Nat Rev Mol Cell Biol. 2011 Mar; 12(3): 141-151.

[11] FERNANDEZ-MARCOS PJ AND AUWERX J. Regulation of PGC-1 $\alpha$, a nodal regulator of mitochondrial biogenesis. Am J Clin Nutr. 2011 Apr; 93(4): 884S-890S.
[12] LIRA VA, BENTON CR, YAN Z, AND BONEN A. $P G C-1 \alpha$ regulation by exercise training and its influences on muscle function and insulin sensitivity. Am J Physiol Endocrinol Metab. 2010 Aug; 299(2): E145-E161.

[13] RIUS-PÉREZ S, TORRES-CUEVAS I, MILLÁN I, ORTEGA AL, AND PÉ S. PGC-1a, Inflammation, and Oxidative Stress: An Integrative View in Metabolism. Oxid Med Cell Longev. 2020; 2020: 1452696.

[14] ILANZA IR, AND NAIR KS. Regulation of Skeletal Muscle Mitochondrial Function: Genes to Proteins. Acta Physiol (Oxf). 2010 Aug; 199(4): 529-547.

[15] SCHREIBER SN, EMTER R, HOCK MB, KNUTTI D, CARDENAS J, MICHAEL PODVINEC $M$, et al. The estrogen-related receptor a (ERRa) functions in PPARY

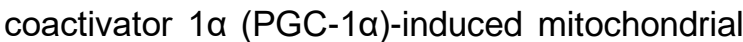
biogenesis. PNAS April 27, 2004101 (17) 64726477.

[16] RAKHSHANDEHROO M, KNOCH B, MÜLLER M, AND KERSTEN S. Peroxisome ProliferatorActivated Receptor Alpha Target Genes. PPAR Res. 2010; 2010: 612089.

[17] PIANTADOSI CA, AND SULIMAN HB. Redox Regulation of Mitochondrial Biogenesis. Free Radic Biol Med. 2012 Dec 1; 53(11): 2043-2053.

[18] CANTÓ C AND AUWERX J. PGC-1alpha, SIRT1 and AMPK, an energy sensing network that controls energy expenditure. Curr Opin Lipidol. 2009 Apr; 20(2): 98-105.

[19] JUNG S AND KIM K. Exercise-induced PGC-1a transcriptional factors in skeletal muscle. Integr Med Res. 2014 Dec; 3(4): 155-160.

[20] JÄGER S, HANDSCHIN C, ST.-PIERRE J, AND SPIEGELMAN BM. AMP-activated protein kinase (AMPK) action in skeletal muscle via direct 
phosphorylation of PGC-1a. PNAS July 17, 2007 104 (29) 12017-12022.

[21] KANG I, CHU CT, AND KAUFMAN BA. The mitochondrial transcription factor TFAM in neurodegeneration: Emerging evidence and mechanisms. FEBS Lett. 2018 Mar; 592(5): 793-811.

[22] KARAKAIDOS P AND RAMPIAS T. Mitonuclear Interactions in the Maintenance of Mitochondrial Integrity. Life (Basel). 2020 Sep; 10(9): 173.

[23] TAANMAN J. The mitochondrial genome: structure, transcription, translation and replication. Ochim Biophys Acta. 1999 Feb 9;1410(2):103-23.

[24] ANGELINI C, BELLO L, SPINAZZI M, AND FERRATI C. Mitochondrial disorders of the nuclear genome. Acta Myol. 2009 Jul; 28(1): 1623.

[25] VAN DER BLIEK AM, SEDENSKY MM, AND MORGAN PG. Cell Biology of the Mitochondrion. Genetics. 2017 Nov; 207(3): 843-871.

[26] RUSECKA J, KALISZEWSKA M, BARTNIK E, AND TOŃSKA K. Nuclear genes involved in mitochondrial diseases caused by instability of mitochondrial DNA. J Appl Genet. 2018; 59(1): 43-57.

[27] FERNÁNDEZ-VIZARRA E AND ZEVIANI M. Nuclear gene mutations as the cause of mitochondrial complex III deficiency. Front Genet. 2015; 6: 134.

[28] SHARMA LK, LU J, AND BAI Y. Mitochondrial Respiratory Complex I: Structure, Function and Implication in Human Diseases. Curr Med Chem. 2009; 16(10): 1266-1277.

[29] LUO S, C. VALENCIA A, ZHANG J, LEE N, SLONE J, GUI B, WANG X, et al. Biparental Inheritance of Mitochondrial DNA in Humans. PNAS December 18, 2018115 (51) 1303913044
[30] SONG W, BALLARD JWO, YI Y, AND SUTOVSKY P. Regulation of Mitochondrial Genome Inheritance by Autophagy and Ubiquitin-Proteasome System: Implications for Health, Fitness, and Fertility. Biomed Res Int. 2014; 2014: 981867.

[31] SUTOVSKY P, MORENO RD, RAMALHOSANTOS J, DOMINKO T, SIMERLY C, SCHATTEN G. Ubiquitinated Sperm Mitochondria, Selective Proteolysis, and the Regulation of Mitochondrial Inheritance in Mammalian Embryos. Biology of Reproduction, Volume 63, Issue 2, 1 August 2000, Pages 582590.

[32] VISSING J. Paternal comeback in mitochondrial DNA inheritance. PNAS January 29, 2019116 (5) 1475-1476; first published January 11, 2019.

[33] TAYLOR RW AND TURNBULL DM. Mitochondrial dna mutations in human disease. Nat Rev Genet. 2005 May; 6(5): 389- 402.

[34] SALAZAR G. NADPH Oxidases and Mitochondria in Vascular Senescence. Int J Mol Sci. 2018 May; 19(5): 1327.

[35] PASSOS JF, SARETZKI G, AHMED S, NELSON G, RICHTER T, PETERS $\mathrm{H}$, et al. T. Mitochondrial dysfunction accounts for the stochastic heterogeneity in telomere-dependent senescence. PLoS Biol. 2007;5.

[36] BONORA M, PATERGNANI S, RIMESSI A, DE MARCHI E, SUSKI JM, ANGELA BONONI A,1 et al. ATP synthesis and storage. Purinergic Signal. 2012 Sep; 8(3): 343-357.

[37] WALLACE DC, FAN W, AND PROCACCIO V. Mitochondrial Energetics and Therapeutics. Annu Rev Pathol. 2010; 5: 297- 348.

[38] KANUNGO S, MORTON J, NEELAKANTAN M, CHING K, SAEEDIAN J, AND GOLDSTEIN A. Mitochondrial disorders. Ann Transl Med. 2018 Dec; 6(24): 475. 
[39] JOHANNSEN DL AND ERIC RAVUSSIN E. The role of mitochondria in health and disease. Curr Opin Pharmacol. 2009 Dec; 9(6): 780-786.

[40] FRYE RE AND ROSSIGNOL DA. Mitochondrial dysfunction can connect the diverse medical symptoms associated with autism spectrum disorders. Pediatr Res. 2011 May; 69(5 Pt 2): 41R-47R.

[41] PEI L AND WALLACE DC. Mitochondrial Etiology of Neuropsychiatric Disorders. Biol Psychiatry. 2018 May 1; 83(9): 722-730.

[42] MCINNES J. Mitochondrial-associated metabolic disorders: foundations, pathologies and recent progress. Nutr Metab (Lond). 2013; 10: 63.

[43] KHAN NA, GOVINDARAJ P, MEENA AK, * AND THANGARAJ K. Mitochondrial disorders: Challenges in diagnosis \& treatment. Indian $\mathrm{J}$ Med Res. 2015 Jan; 141(1): 13-26.

[44] NICOLSON GL. Mitochondrial Dysfunction and Chronic Disease: Treatment With Natural Supplements. Integr Med (Encinitas). 2014 Aug; 13(4): 35-43.

[45] MYHILL S, BOOTH NE, AND MCLARENHOWARD J. Chronic fatigue syndrome and mitochondrial dysfunction. Int $\mathrm{J}$ Clin Exp Med. 2009; 2(1): 1-16.

[46] SCHAEFER AM, WALKER M, TURNBULL DM,A AND TAYLOR RW. Endocrine disorders in mitochondrial disease. Mol Cell Endocrinol. 2013 Oct 15; 379(1-2): 2-11.

[47] GIULIVI C, ZHANG Y, OMANSKA-KLUSEK A, ROSS-INTA C, WONG S, HERTZ-PICCIOTTO I. Mitochondrial Dysfunction in Autism. JAMA. 2010 Dec 1; 304(21): 2389-2396.

[48] GRIFFITHS KK AND LEVY RJ. Evidence of Mitochondrial Dysfunction in Autism: Biochemical Links, Genetic-Based Associations, and Non-Energy-Related Mechanisms. Oxid Med Cell Longev. 2017; 2017: 4314025.

[49] CLAY HB, SILLIVAN S, KONRADI C. Mitochondrial Dysfunction and Pathology in Bipolar Disorder and Schizophrenia. Int J Dev Neurosci. 2011 May; 29(3): 311-324.

[50] ALLEN J, ROMAY-TALLON R, BRYMER KJ, CARUNCHO HJ, AND KALYNCHUK LE. Mitochondria and Mood: Mitochondrial Dysfunction as a Key Player in the Manifestation of Depression. Front Neurosci. 2018; 12: 386.

[51] WALLACE DC. Mitochondria and cancer. Nat Rev Cancer. 2012 Oct; 12(10): 685-698.

[52] GRASSO D, ZAMPIERI LX1, CAPELÔA T, VAN DE VELDE JA1 AND SONVEAUX $P$. Mitochondria in câncer. Cell Stress, Vol. 4, No. 6, pp. $114-146$.

[53] SIVITZ WI AND YOREK MA. Mitochondrial Dysfunction in Diabetes: From Molecular Mechanisms to Functional Significance and Therapeu-

tic Opportunities. Antioxid Redox Signal. 2010

Feb 15; 12(4): 537-577.

[54] CHEN C, TURNBULL DM, AND REEVE AK. Mitochondrial Dysfunction in Parkinson's Disease-Cause or Consequence? Biology (Basel). 2019 Jun; 8(2): 38.

[55] REDDY PM. Mitochondrial Dysfunction and Oxidative Stress in Asthma: Implications for Mitochondria-Targeted Antioxidant Therapeutics. Pharmaceuticals (Basel). 2011 Mar; 4(3): 429456.

[56] CENINI G AND VOOS W. Mitochondria as Potential Targets in Alzheimer Disease Therapy: An Update. Front Pharmacol. 2019; 10: 902.

[57] WEI Y, RECTOR RS, THYFAULT JP, AND IBDAH JA. Nonalcoholic fatty liver disease and mitochondrial dysfunction. World J Gastroenterol. 2008 Jan 14; 14(2): 193-199. 
[58] KOROLCHUK VI, MIWA S, CARROLL B, ZGLINICKI T. Mitochondria in Cell Senescence: Is Mitophagy the Weakest Link? EBioMedicine 21 (2017) 7-13.

[59] VASILEIOU PVS, EVANGELOU K, VLASIS K, FILDISIS G, PANAYIOTIDIS MI, CHRONOPOULOS E, et al. Mitochondrial Homeostasis and Cellular Senescence. Cells. 2019 Jul; 8(7): 686.

[60] JENDRACH M, POHL S, VOTH M, KOWALD A, HAMMERSTEIN P, BEREITER-HAHN J. Morpho-dynamic changes of mitochondria during aging of human endothelial cells. Mech. Aging Dev. 2005;126:813-821.

[61] YOON YS, YOON DS, LIM IK, YOON SH, CHUNG HY, ROJO M, et al. Formation of elongated giant mitochondria in DFO-induced cellular senescence: Involvement of enhanced fusion process through modulation of Fis 1 . J. Cell. Physiol. 2006;209:468-480.

[62] GORMAN GS, CHINNERY PF, DIMAURO S, HIRANO M, KOGA Y, MCFARLAND R, et al. Thorburn D.R., Zeviani M., Turnbull D.M. Mitochondrial diseases. Nat. Rev. Dis. Primers. 2016;2:16080.

[63] TAYLOR RW AND TURNBULL DM. Mitochondrial DNA mutations in human disease. Nat Rev Genet. 2005 May; 6(5): 389- 402.

[64] WHITE FA, BUNN CL. Restriction enzyme analysis of mitochondrial DNA in aging human cells. Mech Ageing Dev. 1985 May 13; 30(2):153-68.

[65] PARK SY, CHOI B, CHEON H, PAK YK, KULAWIEC M, SINGH KK, et al. Cellular aging of mitochondrial DNA-depleted cells. Biochem. Biophys. Res. Commun. 2004;325:1399-1405.

[66] BUTOW RA, AVADHANI NG. Mitochondrial signaling: the retrograde response. Mol Cell. 2004 Apr 9; 14(1):1-15.
[67] DA CUNHA FM, TORELLI NQ, AND KOWALTOWSKI AJ. Mitochondrial Retrograde Signaling: Triggers, Pathways, and Outcomes. Hindawi Publishing Corporation Oxidative Medicine and Cellular Longevity Volume 2015, Article ID 482582, 10.

[68] CAGIN U, ENRIQUEZ JA. The complex crosstalk between mitochondria and the nucleus: What goes in between? Int J Biochem Cell Biol. 2015 Jun; 63():10-5.

[69] GUERRA F, GUARAGNELLA N, ARBINI AA, BUCCI C,GIANNATTASIO S, AND MORO L. Mitochondrial Dysfunction: A Novel Potential Driver of Epithelial-to-Mesenchymal Transition in Cancer. Front Oncol. 2017; 7: 295.

[70] YANG D. KIM J. Mitochondrial Retrograde Signalling and Metabolic Alterations in the Tumour Microenvironment. Cells. 2019 Mar 22;8(3):275.

[71] JIA D, PARK JH, JUNG KH, LEVINE $H$, KAIPPARETTU BA. Elucidating the Metabolic Plasticity of Cancer: Mitochondrial Reprogramming and Hybrid Metabolic States. Cells. 2018 Mar 13; 7(3).

[72] CHANDEL NS. Evolution of Mitochondria as Signaling Organelles. Cell Metab. 2015 Aug 4; 22(2):204-6.

[73] WENG JK, PHILIPPE RN, NOEL JP. The rise of chemodiversity in plants. Science. 2012 Jun 29; 336(6089):1667-70.

[74] LIETAVA J. Medicinal plants in a Middle Paleolithic grave Shanidar IV? J Ethnopharmacol. 1992 Jan; 35(3):263-6.

[75] PETROVSKA BB. Historical review of medicinal plants' usage. Pharmacogn Rev. 2012 Jan-Jun; 6(11): $1-5$.

[76] BUSSMANN RW. The Globalization of Traditional Medicine in Northern Peru: From 
Shamanism to Molecules. Evid Based

Complement Alternat Med. 2013; 2013: 291903.

[77] BLUNT JW, CARROLL AR, COPP BR, DAVIS RA, KEYZERS RA, PRINSEP MR. Marine natural products. Nat Prod Rep. 2018 Jan 16; 35(1):8-53.

[78] Harvey AL, Clark RL, Mackay SP, Johnston BF. Current strategies for drug discovery through natural products. Expert Opin Drug Discov. 2010 Jun; 5(6):559-68.

[79] TANSAZ M, TAJADINI $H$. Comparison of Leiomyoma of Modern Medicine and Traditional Persian Medicine. J Evid Based Complementary Altern Med. 2016 Apr; 21(2):160-3.

[80] THOMFORD NE, AWORTWE C, DZOBO K, ADU $F$, CHOPERA $D$, WONKAM $A$, et al. Inhibition of CYP2B6 by Medicinal Plant Extracts: Implication for Use of Efavirenz and NevirapineBased Highly Active Anti-Retroviral Therapy (HAART) in Resource-Limited Settings. Molecules. 2016 Feb 16; 21(2).

[81] THOMFORD NE, DZOBO K, CHOPERA D, WONKAM A, SKELTON M, BLACKHURST D, CHIRIKURE S, DANDARA C. Pharmacogenomics Implications of Using Herbal Medicinal Plants on African Populations in Health Transition. Pharmaceuticals (Basel). 2015 Sep 21; 8(3):637-63.

[82] RUHSAM M, HOLLINGSWORTH PM. Authentication of Eleutherococcus and Rhodiola herbal supplement products in the United Kingdom. J Pharm Biomed Anal. 2018 Feb 5; 149():403-409.

[83] SOFOWORA A, OGUNBODEDE E, AND ONAYADE A. The Role and Place of Medicinal Plants in the Strategies for Disease Prevention. Afr J Tradit Complement Altern Med. 2013; 10(5): 210-229.

[84] GERTSCH J, LEONTI M, RADUNER S, RACZ I, CHEN J, XIE $X$ et al. Beta-caryophyllene is a dietary cannabinoid. Proc Natl Acad Sci U S A. 2008 Jul 1; 105(26): 9099-9104.

[85] LEGAULT J, PICHETTE A. Potentiating effect of beta-caryophyllene on anticancer activity of alpha-humulene, isocaryophyllene and paclitaxel. J Pharm Pharmacol. 2007 Dec;59(12):1643-7.

[86] HASHIESH HM, MEERAN MFN, SHARMA C, SADEK B, AL KAABI J AND OJHA SK. Therapeutic Potential of $\beta$-Caryophyllene: $A$ Dietary Cannabinoid in Diabetes and Associated Complications. Nutrients 2020, 12(10), 2963

[87] YOUSSEF DA, EL-FAYOUMI HM, MAHMOUD MF. Beta-caryophyllene protects against dietinduced dyslipidemia and vascular inflammation in rats: Involvement of $\mathrm{CB} 2$ and PPAR- $\gamma$ receptors. Chem Biol Interact. 2019 Jan $5 ; 297: 16-24$

[88] CHEN L, LI L, CHEN J, LI L, ZHENG Z, REN J, AND QIU Y. Oleoylethanolamide, an endogenous PPAR- $\alpha$ ligand, attenuates liver fibrosis targeting hepatic stellate cells. Oncotarget. 2015 Dec 15; 6(40): 42530-42540.

[89] OJHA S, JAVED H, AZIMULLAH S, HAQUE ME. $\beta$-Caryophyllene, a phytocannabinoid attenuates oxidative stress, neuroinflammation, glial activation, and salvages dopaminergic neurons in a rat model of Parkinson disease. Mol Cell Biochem. $2016 \mathrm{Jul} ; 418(1-2): 59-70$.

[90] KLAUDYNA FIDYT, ANNA FIEDOROWICZ, LEON STRZADAŁA, AND ANTONI SZUMNY.

$\beta$-caryophyllene and $\beta$-caryophyllene oxidenatural compounds of anticancer and analgesic properties. Cancer Med. 2016 Oct; 5(10): 30073017.

[91] ZHENG, GQ, KENNEY PM, AND LAM LK. Sesquiterpenes from clove (Eugenia caryophyllata) as potential anticarcinogenic agents. J. Nat. Prod. 1992. 55:999-1003. 
[92] PARK K, NAM D, YUN H, LEE S, JANG $H$, SETHI $G$, et al. $\beta$-Caryophyllene oxide inhibits growth and induces apoptosis through the suppression of PI3K/AKT/mTOR/S6K1 pathways and ROS-mediated MAPKs activation. Cancer Lett. 2011 Dec 22;312(2):178-88.

[93] PARK MH and HONG JT. Roles of NF-KB in Cancer and Inflammatory Diseases and Their Therapeutic Approaches. Cells. 2016 Jun; 5(2): 15.

[94] KIM C, CHO SK, KIM K, NAM D, CHUNG W, JANG $H$, et al. $\beta$-Caryophyllene oxide potentiates TNFa-induced apoptosis and inhibits invasion through down-modulation of NF-kBregulated gene products. Apoptosis. 2014 Apr;19(4):708-18.

[95] LANG SJ, SCHMIECH M, HAFNER S, PAETZ C, STEINBORN C, HUBER R, et al. Antitumor activity of an Artemisia annua herbal preparation and identification of active ingredients. Phytomedicine. 2019 Sep; 62:152962.

[96] KONSTAT-KORZENNY E, ASCENCIOARAGÓN JA, NIEZEN-LUGO S, ROSALINO VÁZQUEZ-LÓPEZ R. Artemisinin and Its Synthetic Derivatives as a Possible Therapy for Cancer. Med Sci (Basel). 2018 Feb 27;6(1):19.

[97] CRESPO-ORTIZ MP, WEI MQ. Antitumor activity of artemisinin and its derivatives: from a well-known antimalarial agent to a potential anticancer drug. J Biomed Biotechnol. 2012; 2012:247597.

[98] DU J, ZHANG H · MA Z, JI K. Artesunate induces oncosis-like cell death in vitro and has antitumor activity against pancreatic cancer xenografts in vivo. Cancer Chemother Pharmacol (2010) 65:895-902.

[99] O'NEILL PM, BARTON VE, AND STEPHEN A. WARD SA. The Molecular Mechanism of Action of Artemisinin-The Debate Continues. Molecules. 2010 Mar; 15(3): 1705-1721.
[100]

CHEN G, BENTHANI FA, WU J, LIANG D, BIAN Z AND JIANG $X$. Artemisinin compounds sensitize cancer cells to ferroptosis by regulating iron homeostasis. Cell Death \& Differentiation volume 27, pages242-254(2020)

[101] CRESPO-ORTIZ MP AND WE MQ. Antitumor Activity of Artemisinin and Its Derivatives: From a Well-Known Antimalarial Agent to a Potential Anticancer Drug. J Biomed Biotechnol. 2012;2012:247597.

[102] PAUL BT, MANZ DH, TORTI FM, AND TORTI SV. Mitochondria and Iron: Current Questions. Expert Rev Hematol. 2017 Jan; 10(1): 65-79.

[103] HOROWITZ MP AND GREENAMYRE JT. Mitochondrial Iron Metabolism and Its Role in Neurodegeneration. J Alzheimers Dis. 2010; 20(Suppl 2): S551-S568.

[104] WANG J, HUANG L, LI J, FAN Q, LONG Y, LI Y, AND ZHOU B. Artemisinin Directly Targets Malarial Mitochondria through Its Specific Mitochondrial Activation. PLoS One. 2010; 5(3): e9582.

[105] KRISHNA S, BUSTAMANTE L, HAYNES RK, STAINES HM. Artemisinins: their growing importance in medicine. Trends Pharmacol Sci. 2008 Oct;29(10):520-7.

[106] LI BQ, WEINA P AND HICKMAN M. The Use of Artemisinin Compounds as Angiogenesis Inhibitors to Treat Cancer. Intechopen February 2013.

[107] PIOTR WÓJCIK P, NEVEN ŽARKOVIĆ N, AGNIESZKA GĘGOTEK A, AND ELŻBIETA SKRZYDLEWSKA E. Involvement of Metabolic Lipid Mediators in the Regulation of Apoptosis. Biomolecules. 2020 Mar; 10(3): 402.

[108] RIMMERMAN N, BEN-HAI D, PORAT Z, JUKNAT A, KOZELA E,1 DANIELS MP, et al. Direct modulation of the outer mitochondrial membrane channel, voltage-dependent anion 
channel 1 (VDAC1) by cannabidiol: a novel mechanism for cannabinoid-induced cell death.

Cell Death Dis. 2013 Dec; 4(12): e949.

[109] OLIVAS-AGUIRRE M, TORRES-LÓPEZ L, VALLE-REYES JS, HERNÁNDEZ-CRUZ A, POTTOSIN I AND DOBROVINSKAYA O.

Cannabidiol directly targets mitochondria and disturbs calcium homeostasis in acute lymphoblastic leukemia. Cell Death \& Disease volume 10, Article number: 779 (2019).

[110] RYAN, D, DRYSDALE A.J, LAFOURCADE C, PERTWEE RG. AND PLATT B. Cannabidiol targets mitochondria to regulate intracellular Ca2+ levels. J. Neurosci. 29, 2053-2063 (2009).

[111] ORRENIUS S, GOGVADZE V. \& ZHIVOTOVSKY B. Calcium and mitochondria in the regulation of cell death. Biochem. Biophys. Res. Commun. 460, 72-81 (2015).

[112] GIORGIO V, GUO L, BASSOT C, PETRONILLI V AND BERNARDI P. Calcium and regulation of the mitochondrial permeability transition. Cell Calcium 70, 56-63 (2018). Return to ref 20 in article.

[113] GIACOMELLO M. AND PELLEGRINI, L. The coming of age of the mitochondria-ER contact: a matter of thickness. Cell Death Differ. 23, 1417-1427 (2016).

[114] LOWIN T, TINGTING R, ZURMAHR J, CLASSEN T, SCHNEIDER M, AND PONGRATZ G. Cannabidiol (CBD): a killer for inflammatory rheumatoid arthritis synovial fibroblasts. Cell Death Dis. 2020 Aug; 11(8): 714.

[115] VALERO T. Mitochondrial biogenesis: pharmacological approaches. Curr Pharm Des. 2014;20(35):5507-9.

[116] TEODORO JS, DUARTE FV, GOMES AP, VARELA AT, PEIXOTO FM, ROLO AP, et al. Berberine reverts hepatic mitochondrial dysfunction in high-fat fed rats: a possible role for
SirT3 activation. Mitochondrion. 2013 Nov;13(6):637-46.

[117] NGUYEN PH, GAUHAR R, HWANG SL, DAO TT, PARK DC, KIM JE, et al. New dammarane-type glucosides as potential activators of AMP-activated protein kinase (AMPK) from Gynostemma pentaphyllum. Bioorg Med Chem. 2011 Nov 1;19(21):6254-60.

[118] LEE YS, KIM WS, KIM KH, YOON MJ, CHO HJ, SHEN Y, et al. Berberine, a natural plant product, activates AMP-activated protein kinase with beneficial metabolic effects in diabetic and insulin-resistant states. Diabetes. 2006 Aug;55(8):2256-64.

[119] XIA X, YAN J, SHEN Y, TANG K, YIN J, ZHANG $Y$, et al. Berberine improves glucose metabolism in diabetic rats by inhibition of hepatic gluconeogenesis. PLoS One. 2011 Feb 3;6(2):e16556.

[120] GOMES AP, DUARTE FV, NUNES P, HUBBARD BP, TEODORO JS, VARELA AT, ET AL. Berberine protects against high fat dietinduced dysfunction in muscle mitochondria by inducing SIRT1-dependent mitochondrial biogenesis. Biochim Biophys Acta. 2012 Feb;1822(2):185-95.

[121] CANTÓ C, GERHART-HINES Z, FEIGE JN, LAGOUGE M, NORIEGA L, MILNE JC. AMPK regulates energy expenditure by modulating NAD+ metabolism and SIRT1 activity. Nature. 2009 Apr 23;458(7241):1056-60.

[122] LAN F, CACICEDO JM, RUDERMAN N, IDO Y. SIRT1 modulation of the acetylation status, cytosolic localization, and activity of LKB1. Possible role in AMP-activated protein kinase activation. J Biol Chem. 2008 Oct $10 ; 283(41): 27628-35$.

[123] LEE HS, LIM S, JUNG JI, KIM SM, LEE JK, $\mathrm{KIM} \mathrm{YH}$, et al. Gynostemma Pentaphyllum Extract Ameliorates High-Fat Dietlnduced 
Obesity in C57BL/6N Mice by Upregulating SIRT1. Nutrients 2019, 11(10), 2475.

[124] GAUHAR R, HWANG S, JEONG S, KIM J, SONG H, PARK DC, et al. Heat-processed Gynostemma pentaphyllum extract improves obesity in ob/ob mice by activating AMPactivated protein kinase. Biotechnology Letters. May 2012; 34(9):1607-16.

[125] SHAITO A, THUAN DTB, PHU HT, NGUYEN THD, HASAN H, HALABI $S$, et al. Herbal Medicine for Cardiovascular Diseases: Efficacy, Mechanisms, and Safety. Front Pharmacol. 2020; 11: 422.

[126] LOKMAN EF, GU HF, MOHAMUD WNW, AND CLAES-GÖRAN ÖSTENSON C. Evaluation of Antidiabetic Effects of the Traditional Medicinal Plant Gynostemma pentaphyllum and the Possible Mechanisms of Insulin Release. Evid Based Complement Alternat Med. 2015; 2015: 120572.

[127] YU J AND AUWERX J. Protein deacetylation by SIRT1: an emerging key posttranslational modification in metabolic regulation. Pharmacol Res. 2010 Jul; 62(1): 35-41.

[128] HWANG J, YAO H, CAITO S, SUNDAR IK, AND RAHMAN I. Redox regulation of sirt1 in inflammation and cellular senescence. Free Radic Biol Med. 2013 Aug; 0: 95-110.

[129] BORRA MT, SMITH BC, DENU JM. Mechanism of human SIRT1 activation by resveratrol. J Biol Chem. 2005 Apr 29;280(17):17187-95.

[130] CHAO S, CHEN Y, HUANG K, KUO K, YANG T, HUANG $\mathrm{K}$, et al. Induction of sirtuin-1 signaling by resveratrol induces human chondrosarcoma cell apoptosis and exhibits antitumor activity. Sci Rep. 2017; 7: 3180

[131] BUHRMANN C, SHAYAN P, POPPER B, GOEL A, AND SHAKIBAEI M. Sirt1 Is Required for Resveratrol-Mediated Chemopreventive
Effects in Colorectal Cancer Cells. Nutrients. 2016 Mar; 8(3): 145.

FRAZZI R, VALLI R, TAMAGNINI I, CASALI B, LATRUFFE N, MERLI F. Resveratrolmediated apoptosis of hodgkin lymphoma cells involves SIRT1 inhibition and FOXO3a hyperacetylation. Int J Cancer. 2013 Mar 1; 132(5):1013-21.

[133] ASHRAFIZADEH M, JAVANMARDI S MORADI-OZARLOU M, MOHAMMADINEJAD R, FARKHONDEH T, SAMARGHANDIAN S, SAMARGHANDIAN $S$, et al. Natural products and phytochemical nanoformulations targeting mitochondria in oncotherapy: an updated review on resveratrol. Biosci Rep. 2020 Apr 30; 40(4): BSR20200257.

[134] ZHOU J, ZHOU M, YANG FF, LIU CY, PAN $R L$, CHANG $Q$, et al. Involvement of the inhibition of intestinal glucuronidation in enhancing the oral bioavailability of resveratrol by labrasol containing nanoemulsions. Mol Pharm. 2015 Apr 6; 12(4):1084-95.

[135] WARBURG O. On the origin of cancer cells. Science. 1956 Feb 24; 123(3191):309-14.

[136] KUECK A, OPIPARI AW JR, GRIFFITH KA, TAN L, CHOI M, HUANG J, et al. Resveratrol inhibits glucose metabolism in human ovarian cancer cells. Gynecol Oncol. 2007 Dec; 107(3):450-7.

[137] BLANQUER-ROSSELLÓ MD, HERNÁNDEZ-LÓPEZ R, ROCA P, OLIVER J, VALLE A. Resveratrol induces mitochondrial respiration and apoptosis in SW620 colon cancer cells. Biochim Biophys Acta Gen Subj. 2017 Feb; 1861(2):431-440.

[138] DOMINY JE AND PUIGSERVER P. Mitochondrial Biogenesis through Activation of Nuclear Signaling Proteins. Cold Spring Harb Perspect Biol. 2013 Jul; 5(7): a015008. 
NATHAN L. PRICE NL, ANA P. GOMES AP, ALVIN J.Y. LING AJY, FILIPE V. DUARTE FV, ALEJANDRO MARTIN-MONTALVO A, BRIAN J. NORTH BJ, et al. SIRT1 is required for AMPK activation and the beneficial effects of resveratrol on mitochondrial function. Cell Metab. 2012 May 2; 15(5): 675-690.

[140] DACHE ZA, OTANDAULT A, TANOS R, PASTOR B, MEDDEB R, SANCHEZ $C$, et al. Blood contains circulating cell-free respiratory competent mitochondria. FASEB J. 2020 Mar;34(3):3616-3630.

[141] THIERRY AR, EL MESSAOUDI S, GAHAN PB, ANKER P, AND STROUN M. Origins, structures, and functions of circulating DNA in oncology. Cancer Metastasis Rev. 2016; 35(3): 347-376.

[142] TORRALBA D, BAIXAULI F, AND SÁNCHEZ-MADRID F. Mitochondria Know No Boundaries: Mechanisms and Functions of Intercellular Mitochondrial Transfer. Front Cell Dev Biol. 2016; 4: 107.

[143] RODRIGUEZ A, NAKHLE J, GRIESSINGER E, VIGNAIS M. Intercellular mitochondria trafficking highlighting the dual role of mesenchymal stem cells as both sensors and rescuers of tissue injury. Cell cycle (Georgetown, Tex.) 17(6):1-25. March 2018.

[144] PATEL D, RORBACH J, DOWNES K, SZUKSZTO MJ, PEKALSKI ML AND MINCZUK M. Macropinocytic entry of isolated mitochondria in epidermal growth factor-activated human osteosarcoma cells. Scientific Reports volume 7,
Article number: 12886 (2017).

[145] WANG J, LI H, YAO Y, ZHAO T, CHEN Y, SHEN $Y$, et al. Stem cell-derived mitochondria transplantation: a novel strategy and the challenges for the treatment of tissue injury. Stem Cell Research \& Therapy volume 9, Article number: 106 (2018).

[146] RIBAS V, GARCÍA-RUIZ C AND FERNÁNDEZ-CHECA JC. Glutathione and mitochondria. Front Pharmacol. 2014 Jul 1;5:151

[147] WANG H, JIANG H, CORBET C, DE MEY S, LAW K, GEVAERT T, et al. Piperlongumine increases sensitivity of colorectal cancer cells to radiation: Involvement of ROS production via dual inhibition of glutathione and thioredoxin systems. Cancer Lett. 2019 May 28;450:42-52.

[148] MA Q. Role of Nrf2 in Oxidative Stress and Toxicity. Annu Rev Pharmacol Toxicol. 2013; 53: 401-426.

[149] TU W, WANG H, LI S, LIU Q, AND SHA H. The Anti-Inflammatory and Anti-Oxidant Mechanisms of the Keap1/Nrf2/ARE Signaling Pathway in Chronic Diseases. Aging Dis. 2019 Jun; 10(3): 637-651.

[150] CHIAN S, THAPA R, CHI Z, WANG XJ, TANG $X$. Luteolin inhibits the Nrf2 signaling pathway and tumor growth in vivo. 